\title{
ДМИТРУК В.I.
}

Каф. «Адміністративного забезпечення соціокультурної сфери», ВП «Львівська філія Київського національного університету культури і мистецтв», вул. Кушевича 5, м. Львів, Україна, 79000, тел.. +38 (032) 525195, тел.. +38 (032) 521289 ел. пошта:wid_ua@ukr.net

\section{ПАБЛІК РИЛЕЙШНЗ ЯК ІНСТРУМЕНТ ФОРМУВАННЯ РЕПУТАЦЙНОГО КАПІТАЛУ ПІДПРИЕМСТВ СФЕРИ ТУРИЗМУ}

Мета. Наукове дослідження присвячене розкриттю сутності «паблік рилейшнз» як однієї зі складових управлінських технологій у підприємствах сфери туризму, а також як важливого інструменту формування їх репутаційного капіталу. Методика. Методичною основою цього наукового дослідження є праці зарубіжних авторів, доступна інформація деяких урядових структур, а також інших інтернет-ресурсів. Для вирішення поставлених завдань було проаналізовано низку чинників, які варто враховувати при впровадженні «паблік рилейшнз» у діяльність підприємств сфери туризму, проаналізовано обсяги туристичних потоків за 2013 2017 роки та узагальнено отримані результати. Автор вважає, що є потреба у побудові оновленої структурної моделі програми«паблік рилейшнз» для підприємств сфери туризму. Результати. У роботі запропоновано розроблену автором оновлену структурну модель програми «паблік рилейшнз» для підприємств сфери туризму, впровадження якої у практичну діяльність сприятиме формуванню вищого рівня їх репутаційного капіталу та індивідуалізації відносин зі споживачами. Наукова новизна. Особливою відмінністю при побудові програм «паблік рилейшнз» для підприємств сфери туризму, в сучасних умовах їх функціонування та розвитку, автор вважає необхідним використовувати індивідуальний підхід при визначенні цільової аудиторії, на яку ця програма розрахована. Така потреба зумовлена тим, що визначальні повідомлення, які передаються конкретним цільовим аудиторіям у програмах «паблік рилейшнз» не можуть бути однаковими для всіх аудиторій споживачів. Такі програми повинні враховувати не лише наміри та цілі туристичного підприємства, а також бути збалансованими відповідно цілей конкретної аудиторії споживачів, якій зазначена програма адресована. Практична значимість. Упровадження у практичну діяльність підприємств сфери туризму запропонованої автором оновленої структурної моделі програми «паблік рилейшнз» сприятиме формуванню їх репутаційного капіталу на ринку туристичних послуг, забезпечить вищий рівень індивідуалізації відносин зі споживачами та іншими зацікавленими аудиторіями.

Ключові слова: паблік рилейшнз; реклама; пабліситі; пропаганда; репутація; репутація ділова; імідж; імідж туризму

\section{Постановка проблеми}

Паблік рилейшнз як один із інструментів формування репутаційного капіталу підприємств сфери туризму варто розглядати 3 урахуванням умов, у яких функціонує ринок туристичних послуг на певний момент часу. Саме тому є важливим передбачати можливі майбутні ризики та силу їх впливів. Це дозволить виявити кращі можливості спільної взаємодії учасників ринку туристичних послуг, що забезпечить вищий рівень індивідуалізації відносин зі споживачами та іншими зацікавленими аудиторіями.

\section{Аналіз останніх досліджень і публікацій}

Визначення процесів взаємодії людей i організацій у сучасному суспільстві дозволяє стверджувати, що людство постійно створює нові та змінюе існуючі модуси комунікацій.
Соціальне середовище має здатність постійно змінюватись під впливом низки чинників, що дозволяє утримувати у ньому динамічну рівновагу. Процеси комунікації людей, організацій, підприємств та інших учасників ринку товарів і послуг мають комплексний характер i зумовлюють необхідність їх оптимізації та ефективного розвитку.

До низки відомих зарубіжних науковців, які здійснили вагомий внесок у розвиток теорій «паблік рилейшнз», належать передусім Сем Блек, Френк Джефкінкс, Е. Бернайс, Аллен Сентор і Патрік Джексон, Айві Лі [1, 2, 3, 4]. Виявлено, що вагомий внесок у наукові дослідження процесів комунікативних технологій внесли також науковці: Х. Д. Баркеро Кабреро, Ж. Данкел та Е. Парнхем, Ф. Буарі, Дж. Грюнінг, Г. Брум, Дж. Джеймс, П. Друкер, С. Катліп, А. Сентер та інші [5]. 
Доречно з'ясувати сутність теорій «паблік рилейшнз» деяких авторів. Так, на думку С. Блека, «паблік рилейшнз» - це мистецтво і наука досягнення гармонії шляхом взаєморозуміння, заснованого на правді та повному інформуванні [1, с. 17]. Науковець Френк Джефкінкс вважає, що «паблік рилейшнз» складається із усіх форм запланованих комунікацій із-зовні та у межах організації, а також із громадськістю для реалізації специфічних цілей, спрямованих на досягнення взаєморозуміння [2]. Відповідно до теорії «паблік рилейшнз» Е. Бернайса, автор вважав, що масами можна маніпулювати, апелюючи до їх підсвідомості [3]. Дослідження цього питання у наукових працях Аллена Сентора і Патріка Джексона дозволили їм зробити висновки, що термін «паблік рилейшнз» часто не є однозначним, оскільки використовується 3 різною семантикою. При правильному використанні «паблік рилейшнз» описує процеси практики: техніки, стратегії, структури і тактики ...» [4]. Дослідник процесів комунікації у суспільстві Айві Лі стверджує, що «існує взаємозв'язок між позитивними публікаціями в пресі про фірму або політиків і досягненнями ними нових успіхів [5].

У сучасній практиці управління комплексний розгляд питання щодо використання «паблік рилейшнз», як одного із інструментів формування репутаційного капіталу, передбачає побудову учасниками ринку туристичних послуг зв'язків із громадськістю, публікацій у ЗМІ, проведення наукових семінарів, участь у соціально значимих та благодійних заходах, пабліситі тощо [6].

\section{Формулювання цілей статті (постановка завдання)}

Розкрити сутність категорії «паблік рилейшнз» як однієї зі складових управлінських технологій у підприємствах сфери туризму, а також як важливого інструменту формування їх репутаційного капіталу. Розробити структурну модель програми «паблік рилейшнз» для підприємств сфери туризму, а також виявити чинники, які варто враховувати при іiі практичному впровадженні у діяльність підприємств сфери туризму. Запропонувати прикладні заходи, які сприятимуть формуванню вищого рівня репутаційного капіталу таких підприємств.

\section{Виклад основного матеріалу дослідження}

Мінливість зовнішнього середовища i вплив внутрішніх чинників на діяльність підприємств, обмеженість ресурсів та інші особливості функціонування ринків товарів чи послуг зумовлюють потребу в пошуку ефективних управлінських рішень, що дозволить краще збалансувати такі впливи, знизити рівень ризиків тощо.

Відповідно до теми наукового дослідження щодо сутності та ролі «паблік рилейшнз» як одного із інструментів формування репутаційного капіталу підприємств було виявлено наступне: 1) категорія «репутаційний капітал» може використовуватися стосовно підприємств, окремих осіб, товарів, послуг тощо; 2) категорія «репутація» стосується взаємовідносин між людьми, враховує їх моральні цінності; 3) категорія «репутація підприємств» (гудвіл), як нематеріальний актив підприємств, може змінюватись у часі та бути джерелом високої вартості цих підприємств; 4) «репутацію підприємств» необхідно досліджувати, оцінювати, впроваджувати такі управлінські рішення, які формуватимуть вищий рівень їх «репутаційного капіталу» тощо.

3 огляду на зазначене вище, «паблік рилейшнз» - це також наука, яка вивчає особливості управління громадською думкою та сприяє встановленню взаємовигідних комунікацій, відносин між установами, організаціями та іншими зацікавленими аудиторіями. «Паблік рилейшнз» як діяльність підприємств, організацій, установ та зацікавлених аудиторій спрямовується на покращення взаєморозуміння між ними та передбачає побудову комунікацій із громадськістю, що також сприятиме взаєморозумінню між людьми, органами державного управління тощо. Очевидним $\epsilon$ також те, що «паблік рилейшнз» використовує для досягнення цілей певних аудиторій різні методи, які властиві також таким наукам, як «маркетинг», «менеджмент», «реклама» тощо. Комплексний розгляд цього питання, щодо «паблік рилейшнз» - як одного із інструментів формування репутаційного капіталу підприємств, - передбачає потребу зазначити деякі відмінності між такими категоріями, як «реклама» та «пропаганда». «Реклама» - це оплачена, не особова 
комунікація, яка здійснюється ідентифікованим спонсором і використовує засоби масової інформації 3 метою схилити (до чогось) чи вплинути (якось) на аудиторію [7, с. 35]. Відмінності «реклами» та «паблік рилейшнз» полягають у тому, що остання призначена більш широкій аудиторії ii користувачів, а «реклама» - чітко визначеній категорії споживачів. Потрібно зауважити, що вагомий внесок у розвиток теорії та практики «паблік рилейшнз» на вітчизняних теренах зроблено науковцем Г.Г. Почепцовим. Наукові дослідження Г. Г. Почепцова 3 питань загальних стратегій «паблік рилейшнз», основних підходів i інструментів його впровадження у практичну діяльність, а також i3 формування комунікаційного простору методами «паблік рилейшнз» дозволяють збільшити кількість контрольованих елементів комунікативних процесів, які можна регулювати [6]. Розвідки засвідчили, що існують різні моделі «паблік рилейшнз», які пропонують науковці, а саме: модель пресагентури (пабліситі, пропаганда); модель суспільної інформації; двостороння асиметрична модель; двостороння симетрична модель; двостороння симетрична модель $[1,2$, 3]. Наприклад, Френк Джефкінкс пропонує таку модель «паблік рилейшнз»: 1) оцінка ситуації; 2) визначення цілей; 3) визначення публіки; 4) відбір каналів масової комунікації; 5) планування бюджету; 6) оцінка результатів [6]. Важливою метою «паблік рилейшнз» $є$ встановлення оптимальної взаємодії 3 цільовими аудиторіями. Розглянемо нижче взаємозв’ язок категорій «паблік рилейшнз» та «паблісіті», що означає гласність, популярність підприємства, фірми, компанії; пропаганда, вплив на споживачів із метою збільшення попиту на товари й послуги за допомогою реклами, публікацій і передач у засобах масової інформації, продажу взірців за пільговими цінами, роздачі сувенірів та інше [8, с. 693]. «Паблісіті» - це метод подання новин, які повинні стати надбанням громадськості [9, с. 461]. Огляд наукових джерел засвідчив, що категорії «репутація», «репутаційний капітал», «ділова репутація фірми» тощо знаходяться у певному взаємозв’язку із зазначеними вище категоріями «паблік рилейшнз»і «паблісіті». Розглянемо на прикладі наукових досліджень iз різних джерел, у чому полягає сутність категорій «репутація» та «репутаційний капітал», «ділова репутація фірми» і 3 якими ще категоріями спостерігається їх взаємозв'язок. Дослідження цього питання підтвердили, що категорії «репутація» та «репутаційний капітал» мають різноманітні наукові визначення. Репутаційний капітал, як найбільша цінність підприємств, організацій, установ, окремих осіб тощо, віддзеркалює взаємини між ними та зацікавленими аудиторіями чи групами. Економічна енциклопедія категорію «репутація» характеризує як «загальну думку, що склалася про позитивні якості чи недоліки товару або юридичної особи; про гідність, діловитість (або їх відсутність) людини [10, с. 200]. Виявлено, що особливістю ділової репутації фірми $є$ «оцінка фірми ї суміжниками, підприємцями, споживачами, що характеризується якісними та кількісними показниками [11, с. 353]. Репутація ділова сукупність підтвердженої інформації про особу, що дає змогу можливість зробити висновок про професійні та управлінські здібності такої особи, їі порядність та відповідність іï діяльності певним критеріям [12, с. 494].

У науковій літературі існує ще категорія «імідж», яка за своєю сутністю є близькою у розумінні зазначених вище категорій: «репутація», «репутація ділова», «репутаційний капітал», але має деякі відмінності. 3'ясуємо значення категорії «імідж» та розглянемо деякі відмінності відповідно до таких категорій, як «репутація», «репутація ділова», «репутаційний капітал». Економічна енциклопедія містить таке тлумачення категорії «імідж» - 1) образ товару, послуги, підприємства, фірми тощо, сукупність асоціацій і вражень про них, які формуються у свідомості покупців і які визначають їх становище на ринку; 2) образ ділової людини, уявлення про неї, їі репутація $[11$, c. 625].

За авторами Ф. Котлер та К. Л. Келлер виявлено, що «імідж - це сприйняття компанії чи $\dddot{11}$ товарів суспільством. Яскрава індивідуальність компанії дозволяє іiі виділитися із числа інших конкурентів, здійснює вплив на сприйняття товарів (послуг) споживачами, несе емоційні навантаження , впливає на розум та почуття покупців тощо [13, с. 348]. Дослідження категорії «імідж», згідно енциклопедичного словника із культурології, засвідчили, що «це уявлення про людей i речі, які формуються цілеспрямовано і самою людиною, і засобами 
масової інформації, зокрема рекламою [14, c. 152].

Категорія «імідж» у соціологічній енциклопедії трактується, як «образ, сформована інтерпретація уявлень у суспільній чи індивідуальній свідомості про реальні об'єкти (суб'єкти), явища, процеси тощо [15, с. 150]. Саме «імідж» як один із засобів комунікації може впливати на свідомість різний аудиторій, на масову свідомість та забезпечувати досягнення цілей зацікавлених у таких комунікаціях підприємств, організацій, окремих осіб, масових аудиторій тощо. Імідж підприємства - це його образ, який формується у свідомості певних цільових груп на основі попереднього досвіду взаємодії між ними із інформації та піддається трансформації. Високий рівень іміджу підприємств, організацій, установ тощо дозволяє їм стати власниками довіри споживачів товарів чи послуг та отримувати інші преференції у процесах взаємодії у суспільстві.

Виявлено, що на прикладах діяльності підприємств сфери туризму імідж про них та про їх діяльність формується під впливом індивідуальних характерів покупців туристичних послуг, їх менталітету, їх здатності об'єктивно сприймати отриману інформацію та мотивувати їх поведінку. Імідж підприємств сфери туризму здатний впливати на низку процесів, а саме: на поведінку споживачів, на їх рішення купувати чи не купувати туристичні послуги, на соціальну поведінку окремих груп населення тощо. Дослідження діяльності підприємств сфери туризму показали також певний взаємозв'язок між іміджем підприємств та іміджем України як туристичної країни. «Імідж туризму» сукупність об’єктивних і емоційно суб'єктивних уявлень стосовно конкретної країни, місцевості, які випливають із зіставлення чинників, інформаційних відомостей, сторонніх відгуків і власного досвіду туриста [16, с. 145].

На рівні Міністерства економічного розвитку i торгівлі України здійснюється значна робота по формуванню сприятливого туристичного іміджу країни, проводяться виставково-ярмаркові заходи, що презентують iii туристичні можливості. Слід зазначити, що у 2018 році Міністерство економічного розвитку i торгівлі України організувало проведення низки виставково-ярмаркових заходів, які активізують діяльність підприємств сфери туризму, збільшать кількість туристичних потоків, краще позиціюватимуть Україну на міжнародному ринку туристичних послуг.

До низки заходів, щодо туристичних можливостей України, відносяться наступні: Східно-Середземноморська міжнародна виставка туризму та подорожей «ЕМITT 2018», м. Стамбул, Туреччина, 25 - 27 січня 2018 року;- Міжнародна туристична виставка «ITB Berlin - 2018», м. Берлін, Німеччина, 7 11 березня 2018 року; - «КОТFА», м. Сеул, Республіка Корея, 14 - 17.06.2018 р.; - «China ВITE», м. Пекін, Китай, 15 - 17.06.2018 р.; «IFTM», Міжнародний французький ринок подорожей, м. Париж, Франція, 25 28.09.2018 р.; - «Турбізнес - 2018», м. Мінськ, Республіка Білорусь; - « Україна UITM», м. Київ, Україна, 3 - 5.10.2018 р.; «ITB Asia Signapore 2018», м. Сігнапур, Сігнапур, 17 - 19.10.2018 р.; - «WTM 2018», м. Лондон, Великобританія, 5 - 7.11.2018 р.; «Internatoinal Travel Show TT Warsaw», м. Варшава, Польща, 22 - 24.11.2018 р.; «IBTM 2018», м. Барселона, Іспанія, 27 29.11.2018 р. [17].

Дослідження результатів проведених виставкових заходів, які згадано вище, що сприятимуть формуванню репутаційного капіталу підприємств сфери туризму, дозволяє стверджувати наступне: - виставки допомагають кращому сприйняттю пропозицій туристичних послуг; - виставки дозволяють управляти враженнями покупців щодо товарів, послуг, підприємств, особистостей тощо; - виставки дозволяють завоювати прихильність покупців та лояльність до певних торгових марок, сформувати ефективні відносини із споживачами; - виставки дозволяють вивчити можливості конкурентів та бізнес-партнерів, розширити коло ділових партнерів, збільшити аудиторію майбутніх покупців, стимулювати обсяги продажу товарів і послуг, проінформувати зацікавлені аудиторії про товари чи послуги тощо.

На підставі проведених досліджень цієї теми запропонована оновлена «Структурна модель програми «паблік рилейшнз» для підприємств сфери туризму», особливістю якої $\epsilon$ використання індивідуального підходу при визначенні цільової аудиторії, на яку дана програма розрахована (рис.1). 
Структурна модель програми «паблік рилейшнз» для підприсмств сфери туризму

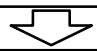

Формування загальних завдань туристичного підприсмства

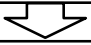

Формування намірів і цілей туристичного підприємства

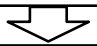

Визначення цільової аудиторії, на кого направлена програма «паблік рилейшнз»

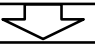

Визначення основних ключових повідомлень, які будуть передані цільовій аудиторії

Визначення стратегії проведення програми «паблік рилейшнз»

Визначення тактики проведення програми «паблік рилейшнз»

\section{ए}

Формування графіка за яким буде проведена програма «паблік рилейшнз»

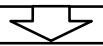

Визначення витрат на проведення програми «паблік рилейшнз»

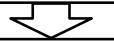

Контроль результатів проведеної програми «паблік рилейшнз»

Рис.1. Структурна модель програми «паблік рилейшнз» для підприємств сфери туризму (укладено автором за джерелом [6])

Імідж України, як туристичної країни, підтверджують також статистичні дані Адміністрації Держприкордонслужби України, які представлені низкою показників.

Представимо деякі з цих показників:

- за 2017 рік усього в Україну в’їхало 14229642 особи 3 інших країн; 3 них за метою поїздки «Туризм» усього - 38958 осіб 3 інших країн. За країнами цей показник характеризується такими даними: 1 Білорусія - 17095 осіб; 2 Туреччина - 7414 осіб; 3 Російська Федерація - 4830 осіб; 4 Ізраїль 2770 осіб; 5 Німеччина - 1419 осіб [20].

За даними Адміністрації Держприкордонслужби України у 2016 році в Україну в’їхало усього -13 333096 осіб 3 інших країн; 3 них за метою поӥздки «Туризм» усього - 172848 осіб з інших країн.
За країнами цей показник характеризується такими даними:1 Білорусія - 84361 особа; 2 Російська Федерація - 44497 осіб; 3 Туреччина - 12192 особи; 4 Ізраїль - 10752 особи; 5 Німеччина - 2978 осіб [20].

Дослідження показника «В’їзд іноземних громадян в Україну за країнами, 3 яких вони прибули, у 2015 році (за даними Адміністрації Держприкордонслужби України) характеризується такими показниками: усього у 2015 році в Україну в'їхало 12428286 осіб 3 інших країн; 3 них за метою поїздки «Туризм» усього - 137906 осіб з інших країн.

За країнами цей показник характеризується такими даними:1-Білорусія, 86752 особи; 2Російська Федерація, 35811 осіб; 3- ША, 3773 особи; 4-Туреччина, 3065 осіб; 5-Ізраїль, 1418 осіб [20]. 
За даними Адміністрації Держприкордонслужби України у 2014 році в Україну в'їхало усього - 12711507 осіб 3 інших країн; 3 них за метою поїздки «Туризм», усього - 146804 особи 3 інших країн.

За країнами показник характеризується такими даними: 1 Білорусія - 67446 осіб; 2 Російська Федерація - 51574 особи; 3 Туреччина - 4885 осіб; 4 Німеччина - 4522 особи; 5 Ізраїль - 3061 особа [20].

Дослідження показника «В”їзд іноземних громадян в Україну за країнами, з яких вони прибули, у 2013 році (за даними Адміністрації Держприкордонслужби України) характеризується такими показниками:усього у 2013 році в Україну в'їхало 24671227 осіб 3 інших країн; 3 них за метою поїздки «Туризм» усього -488496 осіб 3 інших країн.

За країнами цей показник характеризується такими даними: 1 Російська Федерація 270689 осіб; 2 Туреччина - 24515 осіб; 3 Польща - 17908 осіб; 4 Узбекистан - 16282 особи; 5 США - 14390 осіб [20].

Узагальнені зазначені вище показники, які отримані за даними Адміністрації Держприкордонслужби України, за 2013 2017роки щодо в’ізду в Україну іноземних громадян, за країнами, з яких вони прибули 3 метою подорожі «Туризм» подано в табл. 1. [20].

Таблиця 1

В’їзд в Україну іноземних громадян, за країнами, з яких вони прибули, за метою подорожі «Туризм» [20]

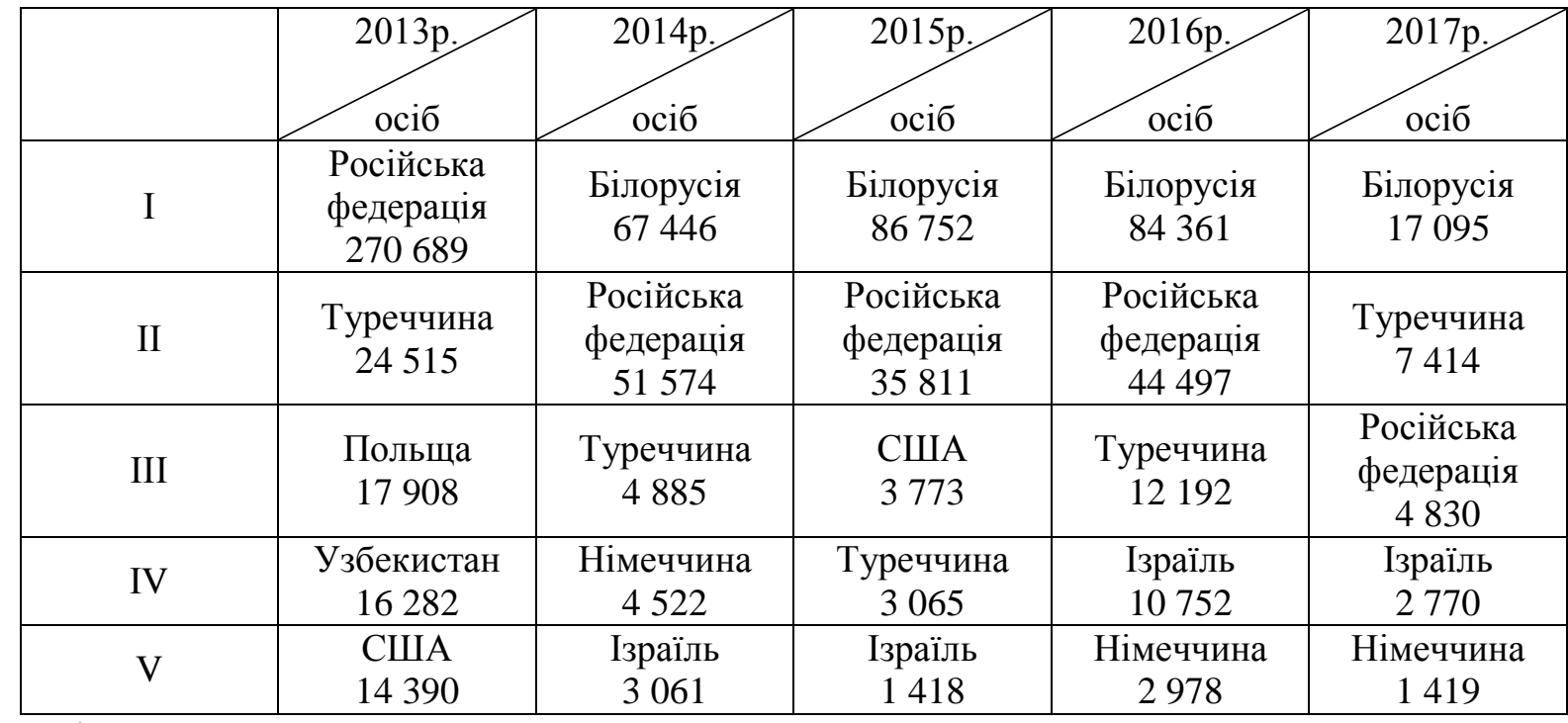

(укладено автором за джерелом [20])

Нижче зображено виявлену тенденцію в'ізду іноземних громадян в Україну, за даними Адміністрації Держприкордонслужби України, за 2013-2017роки (рис. 2), який відображає їх загальну кількість.

На рис. 3. представлено у структурі загальної кількості осіб в’їзду іноземних громадян в Україну - кількість тих осіб, які в'їхали 3 метою поїздки «Туризм». Нижче зображено тенденцію (рис. 4), яка характеризує в’їзд іноземних громадян в Україну за даними Адміністрації Держприкордонслужби України, за 2013 2017роки 3 метою поїздки «Туризм» у загальній структурі осіб, які усього в’їхали в Україну [20].
Потрібно зауважити, що у 2007 році організаційний комітет Топ-форуму «Репутаційний капітал: створення, управління й оцінка» започаткував в Україні діяльність як офіційний представник міжнародної організації США - «Reputation Capital». «Reputation Capital» вивчає репутації вітчизняних підприємств, організацій, установ тощо та ключові фактори їх успіху, оприлюднює отримані результати у 3MI, а також здійснює таку діяльність: реалізує сертифіковані освітні програми із репутаційного менеджменту; організовує конференціі, форуми та семінари на різноманітні тематики; надає послуги iз вимірювання, створення і управління 
репутацією підприємств, організацій, установ тощо [18].

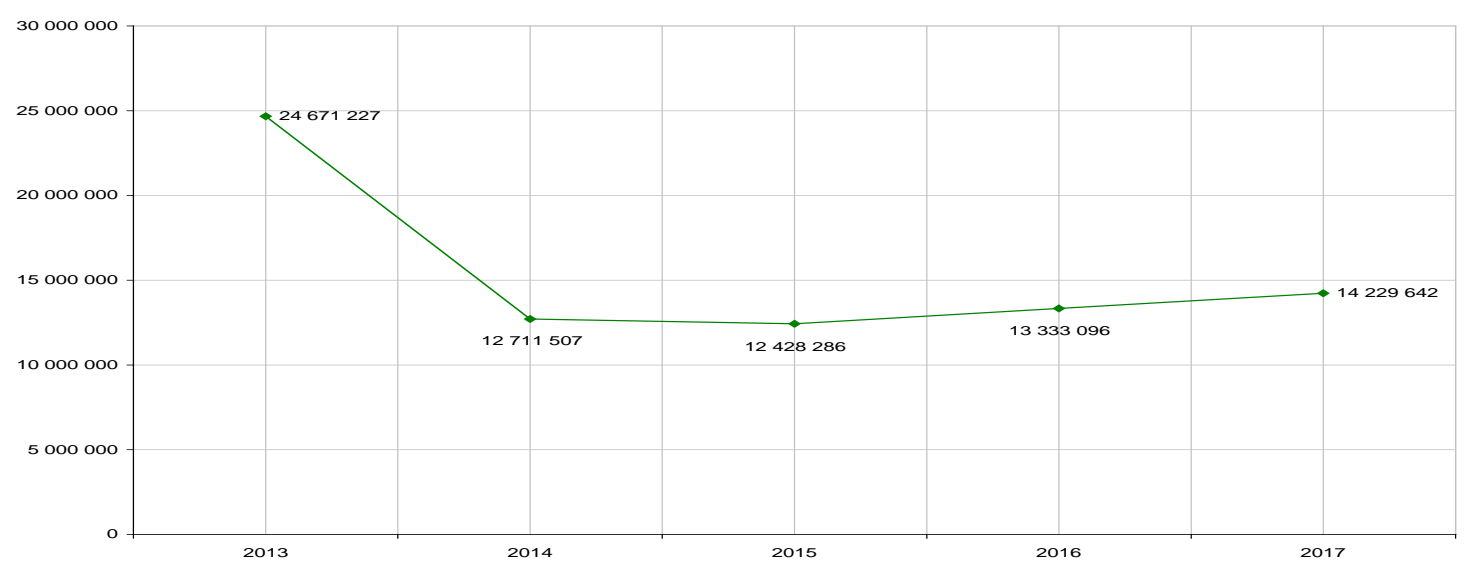

Рис. 2. В'їзд іноземних громадян в Україну, за даними Адміністрації Держприкордонслужби

України, за 2013 - 2017роки (осіб) (укладено автором за джерелом 20)

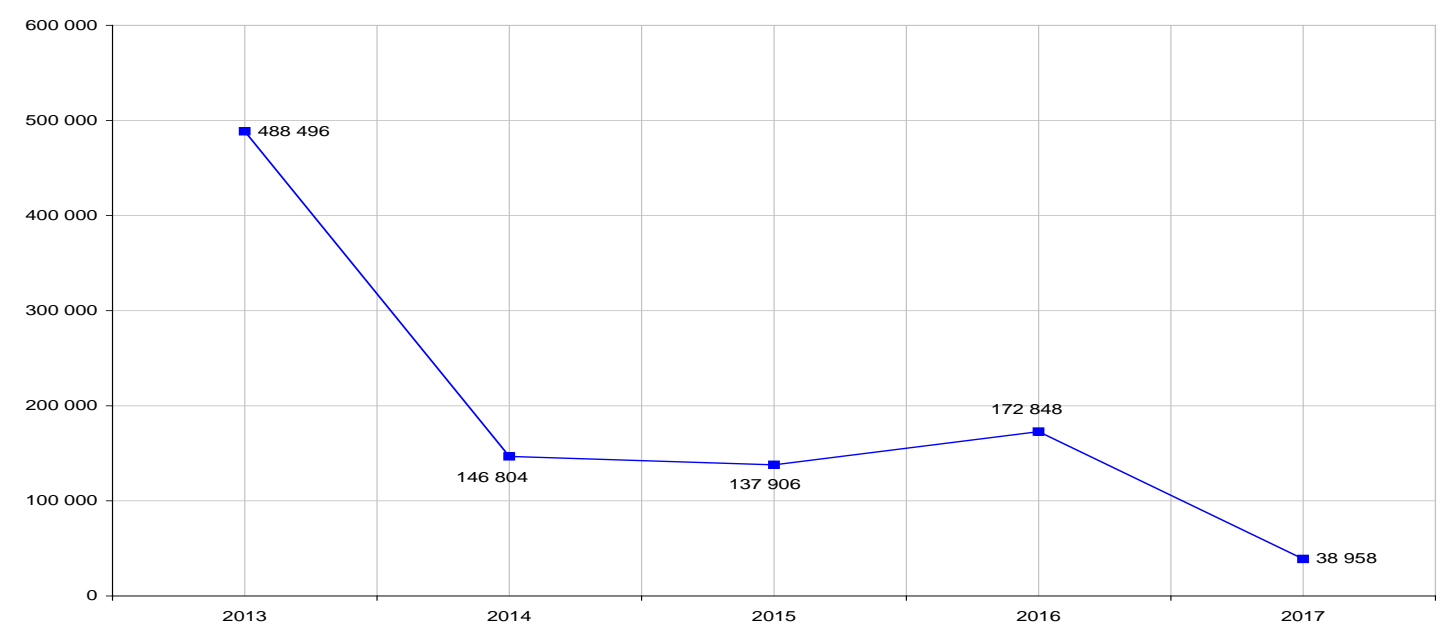

Рис. 3. В'їзд іноземних громадян в Україну, за даними Адміністрації Держприкордонслужби України, за 2013 - 2017 роки, за метою поїздки «Туризм» (осіб)

(укладено автором за джерелом: 20)

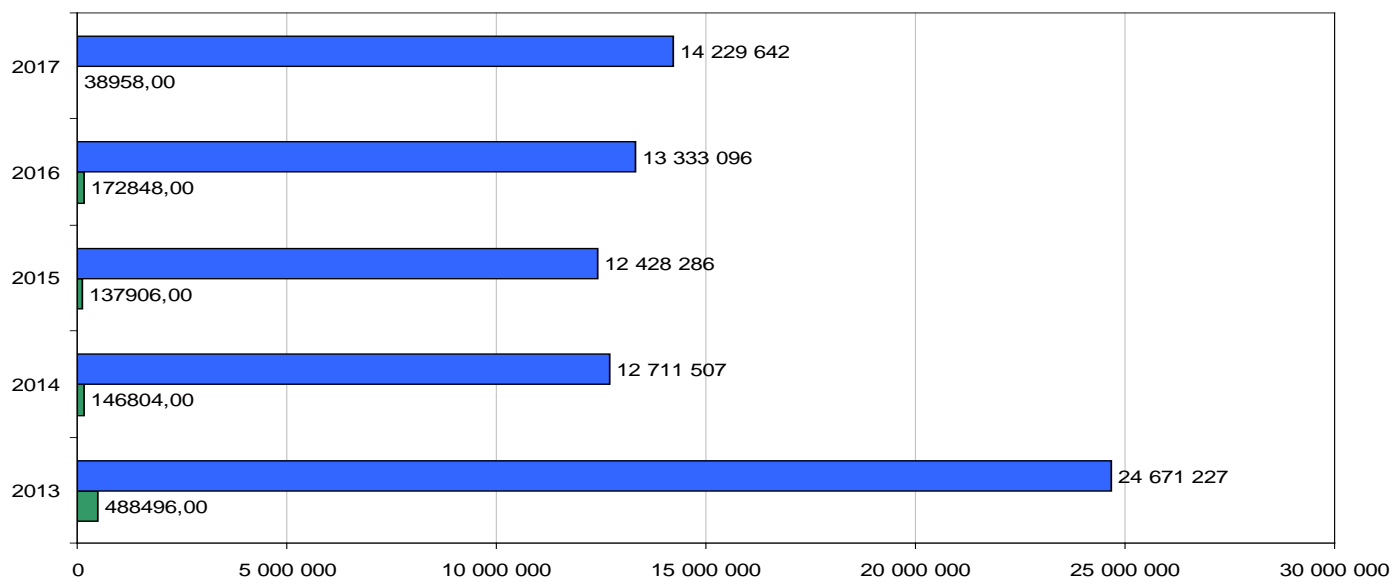

Рис. 4. В'їзд іноземних громадян в Україну, за даними Адміністрації Держприкордонслужби України, за 2013 - 2017 роки, з метою поїздки «Туризм» у загальній структурі осіб, які усього в’їхали в Україну [20]

(укладено автором за джерелом: 20) 
Слід зазначити, що високий рівень активності на ринку послуг медичного туризму спостерігається у діяльності Української Асоціації Медичного Туризму (УАМТ). УАМТ $\epsilon$ великою профільною асоціацією в Україні та в Європі, об'єднуючи низку вітчизняних та міжнародних клінік із багатьох країн світу, співпрацюе 3 багатьма міжнародними організаціями, які надають послуги медичного туризму. Узагальнивши інформацію Української Асоціації Медичного Туризму (УАМТ), яка $є$ доступною на сайті організації, варто зазначити, що «УАМТ активно співпрацює зі ЗМІ, рекламно-інформаційними структурами, піар-компаніями для розвитку медицини i медичного туризму, обміну міжнародним досвідом, пропаганди здорового способу життя.

Експерти УАМТ мають профільну медичну та бізнес-освіту, досвід роботи лікарями і менеджерами медичного туризму [19]. УАМТ позиціюється як партнер «із маркетингу та просування в галузі медичного туризму в Україні; розвиває та захищає репутацію медичного туризму України, у контексті високого рівня якості наданих медичних послуг і міжнародним стандартам профілактики» [19]. Перевагами членства в Українській Асоціації медичного туризму пропонуються для учасників організації наступні можливості: рекламні послуги на сайті УАМТ, організацію реклами під час PR-заходів, організацію взаємодії 3 іншими учасниками ринку медичних послуг тощо.

За даними Української Асоціації медичного туризму у 2017 році зросла на $25 \%$ кількість громадян із-за кордону, які скористалися послугами медичного туризму в Україні, порівняно до 2016 року та становила 62 тис. осіб. Активний попит спостерігався на такі медичні послуги: пластична хірургія, кардіохірургія, ортопедія, репродуктологія, реабілітація людей із ДЦП, стоматологія, офтальмологія. Найбільше туристів купували медичні послуги в Україні 3 таких країн: Молдови, Росії, Білорусії, Німеччини, Італії, Франції, Великобританії, ОАЕ, країни Середньої Азії та Китаю [19].

Відповідно до зазначеного вище можна стверджувати, що ефективне використання інструментів маркетингу по формуванню репутаційного капіталу підприємств сфери медичного туризму, за участі Української Асоціації медичного туризму, сприятиме більш
Review of transport economics and management, 2019, вип.1(17) кращому позиціюванню України у цій сфері діяльності.

У підсумку слід зазначити, що практичне впровадження «паблік рилейшнз» як одного із інструментів формування репутаційного капіталу підприємств сфери туризму вимагає також урахування чинників впливу на ці процеси, які є важливими для сфери туризму.

До низки таких чинників, які варто враховувати при практичному впровадження «паблік рилейшнз» діяльність підприсмств сфери туризму, пропонується віднести наступні:

- інтернаціоналізацію економічного, політичного, культурного життя суспільства, що зумовлює глобалізацію міжнародних відносин, їх взаємодію та взаємозалежність;

- новий розвиток громадської думки в країнах та вплив на неї засобів 3МI;

- вплив різних культур на комунікаційні процеси у мультикультурних середовищах та попередження можливих конфліктів у них;

- глобалізація бізнесу;

- демократизація міжнародних відносин тощо.

Узагальнюючи отримані результати дослідження, відповідно до теми статті, нижче пропонуються практичні заходи, які більш краще сприятимуть формуванню вищого рівня репутаційного капіталу підприємств сфери туризму.

До них варто віднести такі практичні заходи:

1- моніторинг та оцінка інформації у мережі Інтернет, яка впливає на формування репутаційного капіталу підприємств сфери туризму;

2- здійснення аудиту репутаційного капіталу підприємств i його вимірювання; оцінка результатів аудиту репутаційного капіталу підприємств;

3- формування банку даних виявлених позитивних та негативних чинників впливу, у контексті крос-культурних комунікацій, їх аналіз, інтерпретація та використання у взаємодії з іноземними бізнес-партнерами;-

4- планування бюджету на формування репутаційного капіталу підприємств, здійснення контролю бюджету на такі цілі;

5- забезпечення мотивації персоналу підприємств щодо участі у формуванні високого рівня репутаційного капіталу 3 використанням навчальних тренінгів для них;

6- формування стратегій подальших 
Review of transport economics and management, 2019, вип.1(17)

практичних дій підприємствами сфери туризму відповідно проведеного моніторингу інформації у мережі Інтернет, яка впливає на формування репутаційного капіталу підприємств сфери туризму;

7- розробку методології комунікацій із 3МІ відповідно до крос-культурних та міжкультурних особливостей відмінностей учасників туристичного ринку; побудова підприємствами ефективних відносин із масмедіа, контроль подачі інформації для них;

8- побудову комунікаційних процесів, у контексті «паблік рилейшнз» (PR), не лише із споживачами туристичних послуг, а також iз іншими контактними аудиторіями, наприклад: урядовими організаціями, 3MI, бізнеспартнерами; суспільна діяльність підприємств, спонсорство тощо.

Упровадження практичних заходів, які сприятимуть формуванню вищого рівня репутаційного капіталу підприємств сфери туризму, при врахуванні чинників на їх діяльність, сприятимуть більш ефективному розвитку суспільства та міжкультурним комунікаціям, формуванню позитивного іміджу України в світі, а також капіталізації бізнесу тощо.

\section{Висновки}

Підсумовуючи отримані результати дослідження щодо можливостей використання «паблік рилейшнз» як одного із інструментів формування репутаційного капіталу підприємств сфери туризму, було виявлено наступне:

- туристичні підприємства України володіють ресурсами, які необхідні для досягнення поставлених цілей щодо формування ними вищого рівня репутаційного капіталу;

- відповідно до реального стану умов, у яких функціонують підприємства сфери туризму, існують специфічні чинники, які варто враховувати при практичному впровадженні «паблік рилейшнз» у діяльність підприємств сфери туризму.

Запропоновані практичні заходи, впровадження яких у діяльність підприємств сфери туризму, сприятиме формуванню більш вищого рівня їх репутаційного капіталу.

Проблеми, які можуть виникати у процесах формування репутаційного капіталу підприємств сфери туризму, та є необхідними для подальшого дослідження, потребують врахування низки чинників впливу, у т. ч. кроскультурних комунікацій із іноземними партнерами, їх аналіз, інтерпретація тощо.

\section{БІБЛІОГРАФІЧНИЙ СПИСОК}

1. Black S. The essentials of public relations. - London, 1993.

2. JefkinsF. Public Relations. - London, 1992.

3.Bernays E. I. The later years.Public relations insights 1956-1986. - Rhinebeck,1986.

4. CenterA. H. Public Relations practices. - Englewood Cliffs, 1990.

5. Green P. S. WinningPRtactics. - London, 1994.

6. Почепцов Г. Г. Паблікрилейшнз / Г. Г. Почепцов. - Знання, 2006. - 327.

7. Уэллс У. Реклама, принципы и практика/ Уэллс Д., Бернт С. Мориарти;-СПб.: Питер, 2001. $800 \mathrm{c}$.

8. Мочерний С. В., Економічна енциклопедія: у 3-х т. / С. В. Мочерний. - Т.2. - Київ : Академія», 2001. $-848 \mathrm{c}$.

9. Россистер Дж. Р. Реклама и продвижениетоваров / Дж. Р.Россистер, Л. Перси; - СПб: Питер, 2001. $-656 \mathrm{c}$.

10. Мочерний С. В. Економічна енциклопедія: У трьох томах. Т. 3. / С. В. Мочерний - К.: Видавничий центр «Академія», 2002. - 952 с.

11.Мочерний С. В. Економічна енциклопедія : в 3 т. / [Ред. кол. : С. В. Мочерний (відп. ред.) та ін.]. — К. : Видавничий центр «Академія», 2000. — Т. 1. — 864 с.

12.Загородній А.Г., Вознюк Г.Л. Фінансово-економічний словник. -Львів: Вид-во Національного університету «Львівська політехніка», 2005. -714c.

13. Котлер Ф. Маркетинг — Менеджмент / Ф. Котлер, К. Келлер. - СПб. : Питер, 2008. — 814 с. 
Review of transport economics and management, 2019, вип.1(17)

14.МельникВ.П. Культурологія:енциклопедичний словник / В.П.Мельник, М.П.Альчук,Ф.С.Бацевич,І.М.Бойко;за ред..д-ра філос. наук, проф. В.П.Мельника.- Львів: ЛНУ імені Івана Франка, 2013.- 508c.

15.Городяненко В.Г. Соціологічна енциклопедія: /В.Г.Городяненко - К.: Академвидав, 2008.- 456 c.

16.Смолій В. А. Енциклопедичний словник-довідник з туризму / В. А. Смолій, В. К. Федорченко, В. І. Цибух. - К.: Видавничий дім «Слово», 2006. - 372 с.

17.Офіційний сайт Міністерства економічного розвитку і торгівлі України [Електронний ресурс]. Режим доступу: http: // www. me.gov.ua / ( дата звернення 25.02.2019)

18.ReputationCapitalGtroup[Електронний pecypc].-Режим доступу: http: // www. ReputationCapitalGtroup.blog / (дата звернення 25.02. 2019)

19.Офіційний сайт Української Асоціації Медичного Туризму [Електронний ресурс].-Режим доступу: http: // www. uamt.com.ua / (дата звернення 25.02.2019)

20.Офіційний сайт Держприкордонслужби[Електронний ресурс].-Режим доступу: http: // www. dpsu.gov.ua / (дата звернення 25.02.2019)

\section{ДМИТРУК В. И.}

К. филол. наук, доцент каф«Административного обеспечения социокультурной сферы», «Львовский филиал Киевского национального университета культуры и искусств», ул. Кушевича 5, г. Львов, Украина, 79000, тел.. +38 (032) 525195 , тел.. +38 (032) 521289 эл. пошта:wid_ua@ukr.net

\section{ПАБЛИК РИЛЕЙШНЗ КАК ИНСТРУМЕНТ ФОРМИРОВАНИЯ РЕПУТАЦИОННОГО КАПИТАЛА ПРЕДПРИЯТИЙ СФЕРЫ ТУРИЗМА}

Цель. Научное исследование посвящено раскрытию сущности «паблик рилейшнз», как одной из составляющей управленческих технологий в предприятиях сферы туризма, а также как важный инструмент формирования их репутационного капитала. Методика. Методическим основанием данного научного исследования есть труды зарубежных авторов, доступная информация некоторых правительственных структур, а также других сайтов. Для решения поставленных задач было проанализировано ряд факторов, которые стоит учитывать при внедрении «паблик рилейшнз» в деятельность предприятий сферы туризма, проанализировано объемы туристических потоков за 2013 - 2017годы, обобщено полученные результаты. Автор считает, что есть потребность в построении обновленной структурной модели программы «паблик рилейшнз» для предприятий сферы туризма. Результаты. В работе предложено разработанную автором обновленную структурную модель программы «паблик рилейшнз» для предприятий сферы туризма, внедрение которой в практическую деятельность будет содействовать формированию высшего уровня их репутационного капитала, а также индивидуализации отношений с потребителями. Научная новизна. Особенным отличием при построении программ «паблик рилейшнз» для предприятий сферы туризма, в современных условиях их функционирования и развития, автор считает необходимым использовать индивидуальный подход при определении целевой аудитории, на которую эта программа ориентирована. Такая потребность обусловлена тем, что ключевые сообщения, которые передаются конкретным целевым аудиториям в программах«паблик рилейшнз» не могут быть одинаковыми для всех аудиторий потребителей. Такие программы должны учитывать не только намерения и цели туристического предприятия, а также быть сбалансированным и соответственно целей конкретной аудитории потребителей, на которую ориентирована программа. Практическая значимость. Внедрение в практическую деятельность предприятий сферы туризма предложенной автором обновленной структурной модели программы «паблик рилейшнз» будет содействовать формированию их репутационного капитала на рынке туристических услуг, обеспечит высший уровень индивидуализации отношений с потребителями и другими заинтересованными аудиториями.

Ключевые слова: паблик рилейшнз; реклама; паблисити; пропаганда; репутация; репутация деловая; имидж; имидж туризма. 
Dep. “Administrative support of socio-cultural sphere”, Separate subdivision Lviv Branch of Kyiv National University of Culture and Arts, Kushevichst., 5, Lviv, Ukraine, tel +38 (032) 525195 , тел.. +38 (032) 521289 еmail:wid.ua@ukr.net.

\title{
PUBLIC RELATIONS AS A TOOL FOR FORMING THE REPUTATION CAPITAL OF ENTERPRISES IN TOURISM SPHERE
}

\begin{abstract}
Aim. The scientific research is devoted to the disclosure of the essence of "public relations", as one of the components of managerial technology in the tourism industry, as well as an important tool for the formation of their reputational capital. Methodology. The methodological basis of this scientific research is the work of foreign authors, available information of some government structures, as well as other sites. To solve the problems, a number of factors were considered which should be taken into account when introducing "public relations" into the activities of enterprises of the tourism sector, the volumes of tourist flows for 2013-2017 were analyzed and the results were summarized. The author believes that there is a need to build an updated structural model of the program "public relations" for tourism enterprises. Results. The author developed an updated structural model of the "public relations" program for tourism enterprises the introduction of which will in practice contribute to the formation of a higher level of their reputation capital and the individualization of relations with consumers. Scientific novelty. A special difference in the construction of programs "public relations" for enterprises in the sphere of tourism, in modern conditions of their functioning and development, the author considers it necessary to use an individual approach in determining the target audience, for which this program is designed. This need is due to the fact that key messages transmitted to specific target audiences in public relations programs may not be the same for all consumer audiences. Such programs should take into account not only the intentions and objectives of the tourist enterprise but also be balanced in accordance with the goals of the specific consumer audience to which the program is addressed. Practical significance. The implementation in practice of tourism enterprises offered by the author of the revised structural model program "Public Relations" will strengthen their reputational capital in the tourism market and will provide a higher level of individualization relationship with consumers and other interested audiences.
\end{abstract}

Keywords: public relations; advertising, publicity; propaganda; reputation; business reputation; public image; public image of tourism.

\section{REFERENCES}

1. Black S. (1993) The essentials of public relations, London, UK.

2. JefkinsF. (1992) Public Relations, London, UK.

3. Bernays E.I. (1986) The later years. Public relations insights 1956 - 1986, Rhinebeck, USA.

4. Center A.H. (1990) a.o. Public Relations practices, Englewood Cliffs, USA.

5. Green P.S. (1994) Winning PR-tactics, London, UK.

6. Pocheptsov H.H. (2006) Publicrelations, Znannia, Kyiv, Ukraine.

7. Ujells U., Bernt D. and Moriarti S. (2001) Reklama, principy i praktika [Advertising, principles and practice], Piter, Saint Petersburg, Russian Federation.

8. Mochernyj S.V. (2001), Ekonomichna entsyklopediia [Economic Encyclopedia], vol.2, Akademiia, Kyiv, Ukraine.

9. Rossister Dzh. R. And Persi L. (2001) Reklama i prodvizhenie tovarov [Advertising and promotion of goods], Piter, Saint-Petersburg, Russian Federation.

10. Mochernyj S.V. (2002), Ekonomichna entsyklopediia [Economic Encyclopedia], vol.3, Akademiia, Kyiv, Ukraine.

11. Mochernyj S.V. (2000), Ekonomichna entsyklopediia [Economic Encyclopedia], vol.1, Akademiia, Kyiv, Ukraine.

12. Zahorodnij A.H. and Vozniuk H.L. (2005), Finansovo-ekonomichnyj slovnyk [Financial and Economic Dictionary], Vydavnytsvo Natsionalnoho universytetu “Lvivska politekhnika”, Lviv, Ukraine.

13. Kotler F andKeller K., Marketing - Menedzhment [Marketing - Management], Piter, Saint Petersburg, Russian Federation.

14. Melnyk V.P., Alchuk M.P., Batsevych F.S. and Bojko I.M. (2013), Kulturolohiia: entsyklopedychnyj 
Review of transport economics and management, 2019, вип.1(17)

slovnyk [Cultural Studies: An Encyclopedic Dictionary], LNU imeni Ivana Franka, Lviv, Ukraine.

15. Horodianenko V. H. (2008), Sotsiolohichna entsyklopediia [Sociological Encyclopedia], Akademvydav, Kyiv, Ukraine.

16. Smolij V. A., Fedorchenko V. K. And Tsybukh V. I. (2006), Entsyklopedychnyj slovnyk-dovidnyk z turyzmu [Encyclopedic Dictionary-Directory in Tourism], Slovo, Kyiv, Ukraine.

17. Ministry of Economic Developmentand Trade of Ukraine, availableat: http: // www. me.gov.ua (Accessed 25.02. 2019).

18. Reputation Capital Gtroup, available at: http: // www. ReputationCapitalGtroup.blog/ (Accessed 25.02.2019).

19.Ukrainian Association of Medical Tourism, available at: http: // www. uamt.com.ua / (Accessed 25.02. 2019).

20. Officiai site of the state Border Service, available at: http: // www. dpsu.gov.ua/ (Accessed 25.02. 2019).

Надійшла 10.02.2019 p.

Стаття рекомендована до друку д-ром екон. наук, проф. Головковою Л.С., д-ром екон. наук, доц. Бобиль В.В. 